\title{
An Androgen Binding Protein in the Testicular Cytosol of Human Testis
}

\author{
COMPARISON WITH HUMAN PLASMA TESTOSTERONE-ESTROGEN \\ BINDING GLOBULIN
}

\author{
An-Fei Hsu and Philip Troen, Department of Medicine, Montefiore Hospital, \\ and the University of Pittsburgh School of Medicine, Pittsburgh, \\ Pennsylvania 15213
}

\begin{abstract}
A B S T RACT After removal of plasma contamination, an androgen binding protein (hABP) was detected in a $105,000-g$ supernate of human testicular homogenate. The physicochemical properties of hABP have been compared with a similar androgen binding protein in human plasma, testosterone-estrogen binding globulin (TeBG). hABP had high affinity $\left(K_{d}=7.8 \mathrm{nM}\right)$ and low capacity $(0.27 \mathrm{pmol} / \mathrm{mg}$ protein) for $5 \alpha$-dihydrotestosterone (DHT). Binding affinity of human TeBG for DHT was greater $\left(K_{d}=0.66 \mathrm{nM}\right.$, binding capacity $0.68 \mathrm{pmol} / \mathrm{mg}$ protein). On the basis of sedimentation rates and Einstein Stokes radii of hABP and TeBG, the mol wt of the two proteins were similar in the range of $87,000-92,000$. The ligand specificities of hABP and TeBG were the same. The binding of $\left[{ }^{3} \mathrm{H}\right] \mathrm{DHT}$ to hABP and TeBG were reversible processes at $0^{\circ} \mathrm{C}$. The half-lives for the dissociation of $\left[{ }^{3} \mathrm{H}\right] \mathrm{DHT}$ from hABP and TeBG were $100-120 \mathrm{~min}$ and 67-70 min, respectively. Heat sensitivity of hABP and TeBG were similar. hABP had a sharp $\mathrm{pH}$ binding curve with an optimum at 8 , whereas TeBG had a stable $\mathrm{pH}$ optimum between 6.5 and 9. hABP and TeBG were eluted from an ion exchange column at $100 \mathrm{mM}$ and $80 \mathrm{mM}$ sodium chloride concentrations, respectively. Concanavalin A and ricin Sepharose affinity chromatography showed that TeBG is bound to the columns nearly quantitatively, whereas hABP is bound to the columns only partially.

Differences between hABP and TeBG, plus the reduction of plasma contamination as marked by albumin, suggest that the human mature testis contains an androgen binding protein separate from that circulating in plasma.
\end{abstract}

This is paper IX in the series "Studies of the Human Testis." Received for publication 2 September 1977 and in revised form 6 February 1978.

\section{INTRODUCTION}

An androgen binding protein $(\mathrm{ABP})^{1}$ has been extensively studied in the rat and other mammalian species (1-6). ABP has been found in the testis, whence it is secreted into the testicular fluid, and carried to the epididymis. The physicochemical characteristics of ABP distinguish it from cytoplasmic androgen receptors $(7,8)$ and indicates a great similarity to human plasma testosterone-estrogen binding globulin (TeBG) (9). Studies in animals suggest that ABP is under the control of gonadotropins and androgens and that it participates in the transport of androgens within seminiferous tubules as well as to androgen binding epithelial cells in the epididymis $(10,11)$.

The present study reports the presence of an androgen binding protein in human testis (hABP). Physicochemical properties of $\mathrm{hABP}$ are compared to those of TeBG.

\section{METHODS}

Testicular tissue was obtained from patients being treated by orchiectomy for prostatic cancer. The patients had received no prior hormone therapy.

$\left[{ }^{3} \mathrm{H}\right] 1,2-5 \alpha$-dihydrotestosterone (DHT) $(40 \mathrm{Ci} / \mathrm{mmol})$, obtained from New England Nuclear Corporation, Boston, Mass., was purified before use by passage through a Sepha-

\footnotetext{
${ }^{1}$ Abbreviations and trivial names used in this paper: $\mathrm{ABP}$, androgen binding protein; androstanediol, $5 \alpha$-androstan- $3 \beta$, $17 \beta$-diol; androstenediol, 5-androsten- $3 \beta, 17 \beta$-diol; androstenedione, 4 -androstene-3,17-dione; androsterone, $3 \alpha$-hydroxy$5 \alpha$-androstan-17-one; BSA, bovine serum albumin; DHT, dihydrotestosterone, $5 \alpha$-androstan-17 $\beta$-ol-3-one; estradiol $1,3,5$ (10)-estratriene-3,17 $\beta$-diol; hABP, human androgen binding protein; PCMPS, p-chloro-mercuri-phenyl sulfonate; progesterone, 4-pregnene-3,20-dione; TeBG, human testosteroneestradiol binding globulin; $17 \alpha$-testosterone, $17 \alpha$-hydroxy-4androsten-3-one; testosterone,17 $\beta$-hydroxy-4-androsten-3-one.
} 
dex LH-20 column (Pharmacia Fine Chemicals, Inc., Piscataway, N. J.) with the following solvent system: chloroform; $n$-heptane; ethanol (1:1:0.01). The solvent was saturated by water. Tris, sucrose, bovine serum albumin (BSA), pchloro-mercuri-phenyl-sulfonate (PCMPS), protease, and nonradioactive steroids were purchased from Sigma Chemical Co., St. Louis, Mo. The commercial source of other materials used was as follows: rabbit $\gamma$-globulin (IgG), Nutritional Biochemicals Co., Cleveland, Ohio; Insta-Gel for counting radioactive aqueous samples, Packard Instrument Co., Inc., Downers Grove, Ill.; Sephadex G-200 and concanavalin A Sepharose, Pharmacia Fine Chemicals; neuraminidase, Worthington Biochemical Corp., Freehold, N. J.; polyacrylamide and bis-acrylamide, Eastman Kodak Co., Rochester, N. Y.; ricin Sepharose was a gift from Dr. E. C. Heath, Department of Biochemistry, University of Iowa, School of Medicine.

Preparation of crude testicular cytosol. After orchiectomy, the testicular tissue was immediately placed in ice-cold buffer A $(0.5 \mathrm{mM}$ 2-mercaptoethanol, $250 \mathrm{mM}$ sucrose, 0.1 $\mathrm{mM}$ EDTA, and $50 \mathrm{mM}$ Tris-Cl at $\mathrm{pH} 7.4)$. The subsequent procedures were performed at $0-4^{\circ} \mathrm{C}$. The weighed tissue was slightly teased apart and visible blood vessels removed. The tissue was then soaked in buffer $A$ for $10 \mathrm{~min}$, transferred to a small Buchner funnel inserted into a 30-ml glass Sorvall tube (Ivan Sorvall, Inc., Norwalk, Conn.), and gently centrifuged at $1,600 \mathrm{rpm}$ for $5 \mathrm{~min}$. The soaking of testis tissue in buffer $A$ and centrifugation was repeated twice. The tissue was then minced and homogenized in a motor-driven, glass-Teflon, Potter-Elvehjem homogenizer (Arthur H. Thomas Co., Philadelphia, Pa.) with 2-3 vol (wt/vol) of ice-cold buffer $A$. The entire homogenate was centrifuged at $105,000 \mathrm{~g}$ for $60 \mathrm{~min}$ at $2^{\circ} \mathrm{C}$ to obtain the crude testicular cytosol

Removal of endogenous steroids and reconstitution of $h A B P$. The crude testicular cytosol was treated 5:1 (vol/ vol) with concentrated dextran-coated charcoal (5\% charcoal, $0.5 \%$ dextran in buffer $\mathrm{A}$ ) to remove endogenous steroids. After shaking the mixture overnight at $0-4^{\circ} \mathrm{C}$, centrifugation at $12,000 \mathrm{~g}$ for $10 \mathrm{~min}$ yielded the charcoal pellet. Solid ammonium sulfate was added to the clear supernate for a final $40 \%$ concentration and the mixture was again centrifuged at $12,000 \mathrm{~g}$ for $10 \mathrm{~min}$. The precipitated material containing the binding protein was redissolved in buffer $A$ with one-half of the original crude cytosol volume. This reconstituted protein was used in the hABP binding studies carried out in this paper.

Removal of endogenous steroids and reconstitution of TeBG. Human plasma was obtained from a normal blood donor. To remove endogenous steroids, one-fifth volume of concentrated dextran-coated charcoal was added, and the mixture was shaken at room temperature for $45 \mathrm{~min}$. The charcoal was removed by centrifugation at $12,000 \mathrm{~g}$ for 10 min. Ammonium sulfate was added to the supernate to a final $35 \%$ concentration and the mixture was again centrifuged at $12,000 \mathrm{~g}$ for $10 \mathrm{~min}$. The pellet was redissolved to the original plasma volume in buffer $A$. This became the starting material for the TeBG binding studies conducted.

Modified dextran-coated charcoal assay. The method described by Murphy (12) was used with modifications. To measure total binding, a constant $200-\mu \mathrm{l}$ vol of the reconstituted cytosol (containing $600 \mu \mathrm{g}$ to $1.5 \mathrm{mg}$ of protein for each assay) was incubated with $2 \mathrm{nM}\left[{ }^{3} \mathrm{H}\right] \mathrm{DHT}$. Nonspecific binding was determined by incubation with $\left[{ }^{3} \mathrm{H}\right] \mathrm{DHT}$ in the presence of 400-fold excess of unlabeled DHT. After incubation at $0^{\circ} \mathrm{C}$ for $18 \mathrm{~h}, 100 \mu \mathrm{l}$ of concentrated dextran-coated charcoal was added. The mixture was agitated and immediately centrifuged at $2,000 \mathrm{~g}$ for $2-5 \mathrm{~min}$. The entire procedure was carried out as quickly as possible to minimize dissociation of the $\left[{ }^{3} \mathrm{H}\right] \mathrm{DHT}$ from the DHT-protein complex.
Sephadex gel equilibrium. The method of Pearlman and Crepy (13) was used with slight modifications as described by Ritzen et al. (14).

Sucrose gradient centrifugation of $\left[{ }^{3} H\right] D H T-h A B P$ complex. Ultracentrifugation in sucrose gradients was performed as described at Martin and Ames (15), with BSA and $\gamma$ globulin as reference standards. 200- $\mu$ l aliquots of ligandcharged binding proteins were layered on top of $5-20 \%$ (wt/vol) sucrose gradients prepared in buffer A without sucrose with a Buchner gradient apparatus. The gradient was centrifuged at $2^{\circ} \mathrm{C}$ in a Beckman-Spinco ultracentrifuge (L5-65, Beckman Instruments, Spinco Division, Palo Alto, Calif.) for $18 \mathrm{~h}$ at $150,000 \mathrm{~g}$ with a SW 50.1 rotor. After puncturing the tube bottoms, $150-\mu$ l fractions were collected. Protein was determined by measuring optical density at 280 nm with a Zeiss Spectrophotometer (PMQ II, Carl Zeiss, Inc., New York). The sedimentation rate of unknown proteins was calculated from the rate of sedimentation relative to that of BSA (4.6 S) and $\gamma$-globulin (6.9 S).

Polyacrylamide gel electrophoresis (PAGE). The method described by Ritzen et al. (16) was used with slight modifications. Electrophoresis was carried out with $6.5 \%$ gels, prelabeled with $\left[{ }^{3} \mathrm{H}\right] \mathrm{DHT}(2 \mathrm{nM})$ in Tris-glycine buffer ( $\left.\mathrm{pH} 8.3\right)$. A current of $4 \mathrm{~mA} / \mathrm{gel}$ was applied for $3-4 \mathrm{~h}$ at $0-4^{\circ} \mathrm{C}$. After electrophoresis the gels were sliced into 1- or 2-mm segments which were digested with $30 \%$ hydrogen peroxide $\left(0.5 \mathrm{ml}\right.$, at $70^{\circ} \mathrm{C}$ for $\left.2 \mathrm{~h}\right)$. Scintillation fluid was then added for measurement of the radioactivity. $R_{f}$ values were calculated with reference to bromphenol blue.

Determination of stability of hABP. Reconstituted cytosol fractions were prepared as described above and treated as follows: (a) heating at $0,25,37,45,50$, and $60^{\circ} \mathrm{C}$ for 30 min; (b) addition of $1 \mathrm{mM}$ PCMPS and incubation at $30^{\circ} \mathrm{C}$ for $1 \mathrm{~h} ;(c)$ addition of protease (1/20 of binding protein concentration) and incubation at $30^{\circ} \mathrm{C}$ for $1 \mathrm{~h} ;(d)$ absorption overnight at $0^{\circ} \mathrm{C}$ with charcoal $(1 \mathrm{mg} / \mathrm{mg}$ protein). After treatment, the protein was incubated with $2 \mathrm{nM}\left[{ }^{3} \mathrm{H}\right] \mathrm{DHT}$ for $18 \mathrm{~h}$ at $0^{\circ} \mathrm{C}$ and binding activity was determined by the modified dextran-coated charcoal method.

Detection of binding activity after column chromatography. After chromatography, (Sephadex G-200, DEAE cellulose, concanavalin A, ricin affinity column), aliquots of each fraction were incubated with $2 \mathrm{nM}\left[{ }^{3} \mathrm{H}\right] \mathrm{DHT}$ in the presence (for nonspecific binding) or absence (for total binding) of 400 -fold, excess unlabeled DHT. The mixture was incubated for $1 \mathrm{~h}$ at $32^{\circ} \mathrm{C}$ and then $1 / 5$ volume of concentrated dextran-coated charcoal was added, and the mixture was agitated. The charcoal was removed by centrifugation at $3,000 \mathrm{~g}$ for $5 \mathrm{~min}$, and the supernates were assayed for radioactivity after the addition of Insta-Gel (Packard Instrument Co., Inc.) liquid scintillation fluid.

Neuraminidase treatment. $10 \mu \mathrm{g}$ neuraminidase was added to $1 \mathrm{mg}$ protein of hABP or TeBG in buffer A. After incubation at $30^{\circ} \mathrm{C}$ for $1 \mathrm{~h}, 4 \mathrm{nM}\left[{ }^{3} \mathrm{H}\right] \mathrm{DHT}$ was added and the incubation was continued at $32^{\circ} \mathrm{C}$ for another hour. Control incubations were performed without neuraminidase. After completion of the incubation, PAGE was carried out to determine if there was any change in mobility after neuraminidase treatment.

Other analytical methods. Radioactivity was measured in a Packard Tri-Carb scintillation counter (model 544) with Insta-Gel liquid scintillation fluid.

Total protein was determined by the method of Lowry et al. (17).

\section{RESULTS}

Removal of plasma contamination from human testicular cytosol. Initial preparations of crude cyto- 
sol free of endogenous steroids demonstrated androgen binding activity. However, because of the known binding activity of human plasma TeBG, it was necessary to minimize possible contamination of the testicular cytosol by plasma to allow definition of the characteristics of the testicular androgen binding capacity. For this purpose, albumin, which also binds $\left[{ }^{3} \mathrm{H}\right] \mathrm{DHT}$, was used as a marker of plasma contamination.

PAGE of conventionally prepared cytosol revealed two peaks of binding to $\left[{ }^{3} \mathrm{H}\right] \mathrm{DHT}$, one corresponding to authentic albumin $\left(\mathrm{R}_{f}=0.68\right)$ and a second broader peak $\left(\mathrm{R}_{f}=0.37\right)$. After modification of the conventional method by addition of the soaking and gentle centrifugation procedures as described above, the crude cytosol free of endogenous steroids showed $90 \%$ reduction of the albumin binding peak and narrowing of the other $\left[{ }^{3} \mathrm{H}\right] \mathrm{DHT}$ binding peak. The final cytosol used for the present studies was prepared after both presoaking and $40 \%$-ammonium sulfate precipitation as described above. This eliminated the residual albumin. leaving a single androgen binding peak.

In comparison, the androgen binding of native human serum revealed two major radioactive peaks, one corresponding to albumin $\left(\mathrm{R}_{f}=0.68\right)$ and a second peak $\left(\mathrm{R}_{f}=0.34\right)$ corresponding to TeBG. The ratio of albumin to TeBG was 1:0.4-0.6. Thus, the presence of plasma components in a cytosol preparation might give a spurious indication of the nature of the androgen binding activity of the testis. The absence of marker albumin indicates the removal of plasma contamination by the method of preparation used. Further studies were then performed with testicular cytosol prepared in this fashion. The protein from human testicular cytosol which binds to $\left[{ }^{3} \mathrm{H}\right] \mathrm{DHT}$ is referred to as hABP.

During the above studies it was noted that TeBG and hABP have slightly different mobilities on PAGE. On 5, 6.5, and $8 \%$ gels, TeBG had mobilities of $0.41,0.34$, and 0.27 , respectively, whereas hABP had mobilities of $0.44,0.37$, and 0.3 , respectively. Although hABP moves slightly faster than TeBG on PAGE, it is not possible to completely separate them in this fashion.

Time course of specific binding of $\left[{ }^{3} \mathrm{H}\right] \mathrm{DHT}$ to $h A B P$. Association of $\left[{ }^{3} \mathrm{H}\right] \mathrm{DHT}$ with reconstituted $\mathrm{hABP}$ at various times was studied. Maximum specific binding was reached after $2 \mathrm{~h}$ at $0^{\circ} \mathrm{C}$ and the proteinligand complex remained stable for $24 \mathrm{~h}$. When binding was studied at $32^{\circ} \mathrm{C}$, specific binding reached a maximum by $30 \mathrm{~min}$ and remained stable for up to $3 \mathrm{~h}$. The metabolism of $\left[{ }^{3} \mathrm{H}\right]$ DHT to other steroids during the incubation of reconstituted $\mathrm{hABP}$ at $0^{\circ} \mathrm{C}$ overnight was negligible. In contrast, incubation of conventionally prepared cytosol leads to a significant 5-10\% conversion of $\left.{ }^{3} \mathrm{H}\right] \mathrm{DHT}$ to $5 \alpha$-androstanediol. Because of the longer stability at $0^{\circ} \mathrm{C}$, subsequent experiments were performed at this temperature.
Effect of $\left[{ }^{3} H\right] D H T$ concentration on the binding of $\left[{ }^{3} H\right] D H T$ to $h A B P$. The binding of $\left[{ }^{3} \mathrm{H}\right] \mathrm{DHT}$ to hABP was dependent upon the concentration of $\left[{ }^{3} \mathrm{H}\right] \mathrm{DHT}$. With the modified dextran-coated charcoal assay, it was found that specific binding of $\left[{ }^{3} \mathrm{H}\right] \mathrm{DHT}$ to reconstituted hABP was linear up to $1.5 \mathrm{pmol}$ and was saturated around $2.0 \mathrm{pmol}$ of $\left[{ }^{3} \mathrm{H}\right] \mathrm{DHT}$.

A Scatchard plot of the data yields a straight line indicating a single class of binding sites with a high affinity for $\left[{ }^{3} \mathrm{H}\right] \mathrm{DHT}$. An apparent dissociation constant $\left(K_{d}\right)$ of the ligand-binding protein of $7.8 \mathrm{nM}$ was obtained. From the intercept on the abscissa, a binding capacity of $0.27 \mathrm{pmol} / \mathrm{mg}$ protein was calculated.

To substantiate the validity of the modified dextran-coated charcoal assay for the above determination, $\left[{ }^{3} \mathrm{H}\right] \mathrm{DHT}$ binding activity was also measured by Sephadex gel equilibrium. Scatchard plot analysis of these results yielded a $K_{d}$ of $7.0 \mathrm{nM}$. Because the $K_{d}$ values obtained by both methods were in good agreement, we subsequently used the modified dextrancoated charcoal assay because of its greater convenience. The $\boldsymbol{K}_{\boldsymbol{d}}$ value of TeBG obtained by dextrancoated charcoal assay was $0.66 \mathrm{nM}$, and the binding capacity was $0.68 \mathrm{pmol} / \mathrm{mg}$ protein.

Sedimentation rate of $h A B P$. Testicular cytosol was studied by ultracentrifugation on sucrose gradients. At low ionic strength $(0.01 \mathrm{M} \mathrm{KCl})$ the $\left[{ }^{3} \mathrm{H}\right] \mathrm{DHT}$ bound protein migrated in a slightly broad peak with a sedimentation rate of $\sim 4.6 \mathrm{~S}$ (Fig. 1A). This complex moved at the same rate of $4.6 \mathrm{~S}$ in high ionic strength $(0.4 \mathrm{M} \mathrm{KCl})$ gradients (Fig. 1B). No aggregation was detected in the bottom of the tubes or in the $8-10 \mathrm{~S}$ region.

Molecular weight of $h A B P$. Sephadex gel filtration of human testicular cytosols gave one major peak of

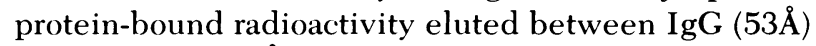
and albumin $(36 \AA)$ and a minor peak of protein-bound radioactivity which was excluded from Sephadex G-200. $90 \%$ of the radioactivity of the minor peak could not be displaced by nonradioactive DHT. It appears, therefore, that the high molecular weight minor peak was because of nonspecific binding. With the equations of Laurent and Killander (18) the Einstein-Stokes radius of the major protein-bound peak of radioactivity was calculated to be $47 \AA$.

With the Stokes radius ( $47 \AA)$ determined by gel filtration and the sedimentation coefficient (4.5-4.7 S) determined by gradient centrifugation, the molecular weight for nonglobular proteins can be estimated from the equation $\mathrm{M}=6 \pi \eta \mathrm{Na} S(1-\bar{v} \rho)$ where $\eta$ = viscosity of the medium, $\mathrm{N}=$ Avogadro's number, $\mathrm{a}$ $=$ Stokes radius, $\mathrm{S}=$ sedimentation coefficient, $\overline{\mathrm{v}}=$ partial specific volume $\left(0.725 \mathrm{~cm}^{3} / \mathrm{g}\right)$, and $\rho=$ density of the medium. The mol wt of hABP was calculated as 87-90,000. Under similar conditions, the mol wt of TeBG was determined to be $88-92,000$ with the Stokes radius of $47 \AA$ and sedimentation rate of 4.6-4.8 S. 


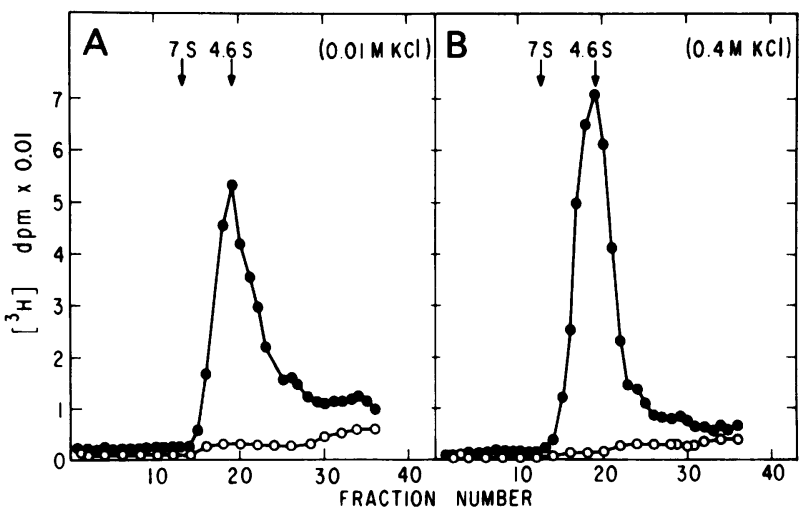

FIGURE 1 Sedimentation characteristics of $\left[{ }^{3} \mathrm{H}\right] \mathrm{DHT}$ hABP complex. hABP ( $1 \mathrm{mg}$ protein) in buffer A without sucrose was incubated with $2 \mathrm{nM}\left[{ }^{3} \mathrm{H}\right] \mathrm{DHT}$ in the absence $(-)$ ) or presence $(\mathrm{O}-\mathrm{O})$ of 400 -fold, excess, unlabeled DHT at $0^{\circ} \mathrm{C}$ for $2 \mathrm{~h}$. Excess $\left[{ }^{3} \mathrm{H}\right] \mathrm{DHT}$ was removed by the addition of $100 \mu \mathrm{l}$ of concentrated dextran-coated charcoal (5\% charcoal, $0.5 \%$ dextran in buffer A). The mixture was immediately centrifuged at $2,000 \mathrm{~g}$ for $2-5$ min. A 200- $\mu$ l aliquot was removed and layered on a linear $5-20 \%$ sucrose gradient either in the absence (A) or the presence (B) of $0.4 \mathrm{M} \mathrm{KCl}$. The gradient was centrifuged at $2^{\circ} \mathrm{C}$ for $18 \mathrm{~h}$ at $150,000 \mathrm{~g}$ by a SW 50.1 rotor. $150-\mu$ l fractions were collected for measurement of radioactivity. Protein was determined by measuring the optical density at $280 \mathrm{~nm}$. BSA (4.6 S) and $\gamma$-globulin $(6.9 \mathrm{~S})$ were used as reference standards for calculating the sedimentation rate of hABP.

Competitive inhibition of hABP and TeBG by nonlabeled steroids. Various concentrations of unlabeled steroids were incubated with $2 \mathrm{nM}\left[{ }^{3} \mathrm{H}\right] \mathrm{DHT}$ to determine competition for specific binding sites in hABP and TeBG. At low concentration of DHT (10 nM) there was marked inhibition of $\left[{ }^{3} \mathrm{H}\right] \mathrm{DHT}$ binding for both hABP and TeBG. Steroids with the same $17 \beta$ $\mathrm{OH}$ group in the D ring (testosterone, androstanediol, and androstenediol) also inhibited but required higher concentrations $(0.2 \mu \mathrm{M})$ for a similar degree of inhibition. Substituting a ketone group for the $17 \beta-\mathrm{OH}$ group resulted in diminished ability to inhibit androgen binding; progesterone, androstenedione, and androsterone were poor inhibitors even at very high concentrations. Changing the $\mathrm{A}$ ring to an aromatic (estradiol-17 $\beta$ ) ring showed inhibition only at high concentration $(2.0 \mu \mathrm{M})$. The order of affinity of hABP and TeBG to various ligands appears to be as follows: dihydrotestosterone $>$ androstanediol $>$ testosterone $>$ androstenediol $>$ estradiol-17 $\beta>$ progesterone $\cong$ androstenedione $\cong$ androsterone.

From the above data, it seems that hABP binds to steroids from the $\beta$ position of the $D$ ring. Substitution

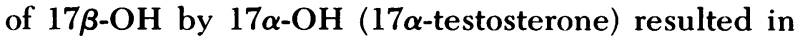
diminution of the inhibitory effect.

Dissociation of $\left[{ }^{3} H\right] D H T-h A B P$ and $\left[{ }^{3} H\right] D H T-T e B G$ complexes by nonlabeled DHT. hABP and TeBG, respectively, were allowed to bind $\left[{ }^{3} \mathrm{H}\right] \mathrm{DHT}$ maximally. Excess unlabeled DHT was added to the reaction and the rate of exchange of the ligand was measured as a function of time by the modified dextrancoated charcoal procedure. As indicated in Fig. 2, the specific binding of $\left[{ }^{3} \mathrm{H}\right] D H T$ to hABP and of $\left[{ }^{3} \mathrm{H}\right]-$ DHT to TeBG was a reversible process at $0^{\circ} \mathrm{C}$. The half-life was $120 \mathrm{~min}$ for $\left[{ }^{3} \mathrm{H}\right] \mathrm{DHT}-\mathrm{hABP}$ and $70 \mathrm{~min}$ for $\left.{ }^{3} \mathrm{H}\right] \mathrm{DHT}-\mathrm{TeBG}$. Kinetics of dissociation were not measured at higher temperatures.

A second method was used to estimate the rates of dissociation of the two complexes. hABP or TeBG which had bound to $\left[{ }^{3} \mathrm{H}\right] \mathrm{DHT}$ maximally was treated with a suspension of dextran-coated charcoal and then the quantity of bound $\left[{ }^{3} \mathrm{H}\right] \mathrm{DHT}$ was measured as a function of time. The half-life of dissociation was 100 $\min$ for $\left[{ }^{3} \mathrm{H}\right] D H T-h A B P$ and $67 \mathrm{~min}$ for $\left[{ }^{3} \mathrm{H}\right] \mathrm{DHT}-$ TeBG. By both methods the half-life of dissociation was longer for the hABP complex than for the TeBG complex with reasonable agreement of the respective values.

Heat sensitivity of $h A B P$ and TeBG. hABP and TeBG did not retain their binding activity when exposed to temperatures over $45^{\circ} \mathrm{C}$ for $30 \mathrm{~min}$. The relation of binding activity to temperature treatment was similar for both binding proteins except that hABP was slightly less stable at $37^{\circ} \mathrm{C}$.

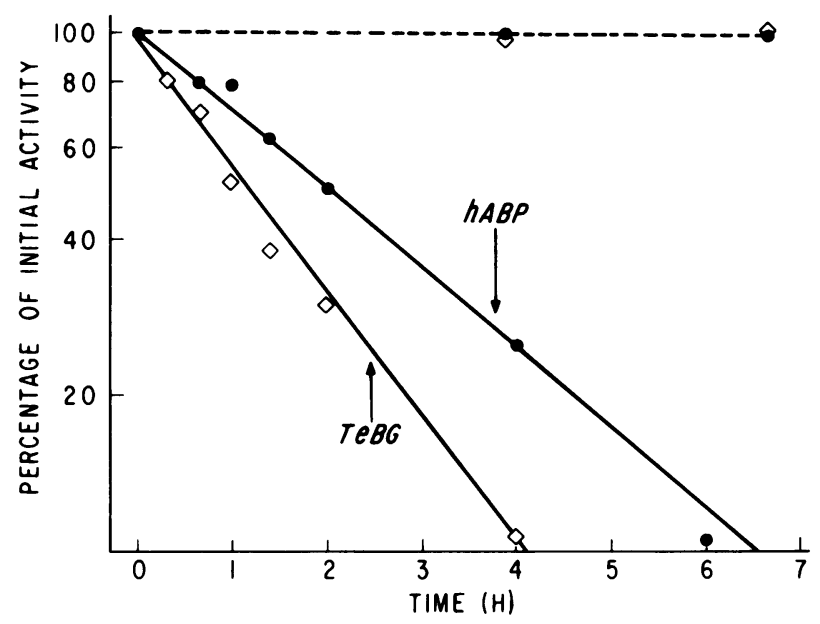

FIgURE 2 The dissociation of $\left[{ }^{3} \mathrm{H}\right]$ DHT-hABP and H-DHTTeBG complexes by nonlabeled DHT. hABP or TeBG (800 $\mu \mathrm{g}$ of protein in each incubation) and $\left[{ }^{3} \mathrm{H}\right] \mathrm{DHT}$ in buffer $\mathrm{A}$ $(200 \mu \mathrm{l})$ were incubated at $0^{\circ} \mathrm{C}$ overnight to allow maximal binding. A 400-fold excess of nonradioactivity DHT was then added to the incubating mixture containing hABP $(\bullet-\odot)$ or TeBG $(\diamond-\diamond)$. The mixture was further incubated at $0^{\circ} \mathrm{C}$ for various times as indicated. The control experiments (hABP $\bullet---\bullet$, and TeBG $\diamond---\diamond$ ) were performed in the absence of nonlabeled DHT. Excess $\left[{ }^{3} \mathrm{H}\right] \mathrm{DHT}$ was removed as described in Fig. 1 and radioactivity was measured in a $200-\mu$ l aliquot. Maximum binding at zero time (initial activity) was used as $100 \%$ for the calculation of dissociation percentage. 
Addition of DHT before heat treatment did not prevent the denaturation of the DHT-hABP complex at 45,50 , or $60^{\circ} \mathrm{C}$.

Optimal $\mathrm{pH}$ for binding. The effect of $\mathrm{pH}$ of the incubation mixture on binding of hABP and TeBG to $\left[{ }^{3} \mathrm{H}\right] \mathrm{DHT}$ was studied. hABP in testicular cytosol showed optimal binding at $\mathrm{pH} 8$ with a sharp decrease in activity at higher or lower $\mathrm{pH}$ values. The $\left[{ }^{3} \mathrm{H}\right]$ DHT-hABP complex was not stable below pH 6 or above $\mathrm{pH} 9$; binding was irreversibly destroyed below $\mathrm{pH} 5$ and above $\mathrm{pH}$ 10. TeBG had a similar $\mathrm{pH}$ optimum but displayed a higher degree of activity at pH 6.5 and $\mathrm{pH} 9$, with a stable $\left[{ }^{3} \mathrm{H}\right] \mathrm{DHT}-\mathrm{TeBG}$ complex between $\mathrm{pH} 6.3$ and 9, and a bell-shaped curve.

Ion exchange chromatography. hABP and TeBG were separately fractionated on DEAE cellulose (Whatman DE-52, Whatman, Inc., Clifton, N. J.) columns with linear gradients of $\mathrm{NaCl}$ in $0.01 \mathrm{M}$ Tris buffer ( $\mathrm{pH}$ 7.4). The binding peak of hABP was eluted at $100 \mathrm{mM} \mathrm{NaCl}$ whereas TeBG showed a binding peak at $80 \mathrm{mM} \mathrm{NaCl}$ (Fig. 3). When both hABP and TeBG were examined together on DEAE cellulose columns, one broad peak, spread over $80-100 \mathrm{mM}$ $\mathrm{NaCl}$, was observed. After chromatography, hABP sedimented at $4.6 \mathrm{~S}$ as did human testicular cytosol before chromatography, indicating no change in the protein in this respect. It appears from these data that hABP is slightly more acidic than TeBG, but the two proteins cannot be separated by this method.

Concanavalin A Sepharose and ricin Sepharose affinity chromatography. The possibility that hABP may be a glycoprotein like TeBG was studied with plant lectin affinity resins. hABP and TeBG were fractionated on concanavalin A Sepharose which specifically binds to mannose or glucose residues of glycoprotein. As shown in Fig. 4, more than 95\% of TeBG was absorbed by the affinity resin and subsequently eluted with $10 \% \alpha$-methylglucoside in the eluting buffer. hABP was partially $(47 \%)$ absorbed by the affinity resin and then eluted with $10 \% \alpha$-methylglucoside in the eluting buffer. Differences in percentage of protein bound to the gel may have resulted from differences in amount of configuration of mannose or glucose in the glycoproteins.

Ricin Sepharose is a lectin affinity gel which binds to glycoproteins having galactose residues. When hABP and TeBG were fractionated on ricin Sepharose (Fig. 5), 100\% of the TeBG bound to the gel whereas $\sim 60 \%$ of the hABP was bound. The material bound to the gel was eluted with $0.2 \mathrm{M}$ D-galactose in the eluting buffer.

Treatment with neuraminidase. To study the sialic acid content of the binding proteins, they were treated with neuraminidase. The binding activity of hABP and TeBG was not affected by the neuraminidase treatment. However, when examined by PAGE, the

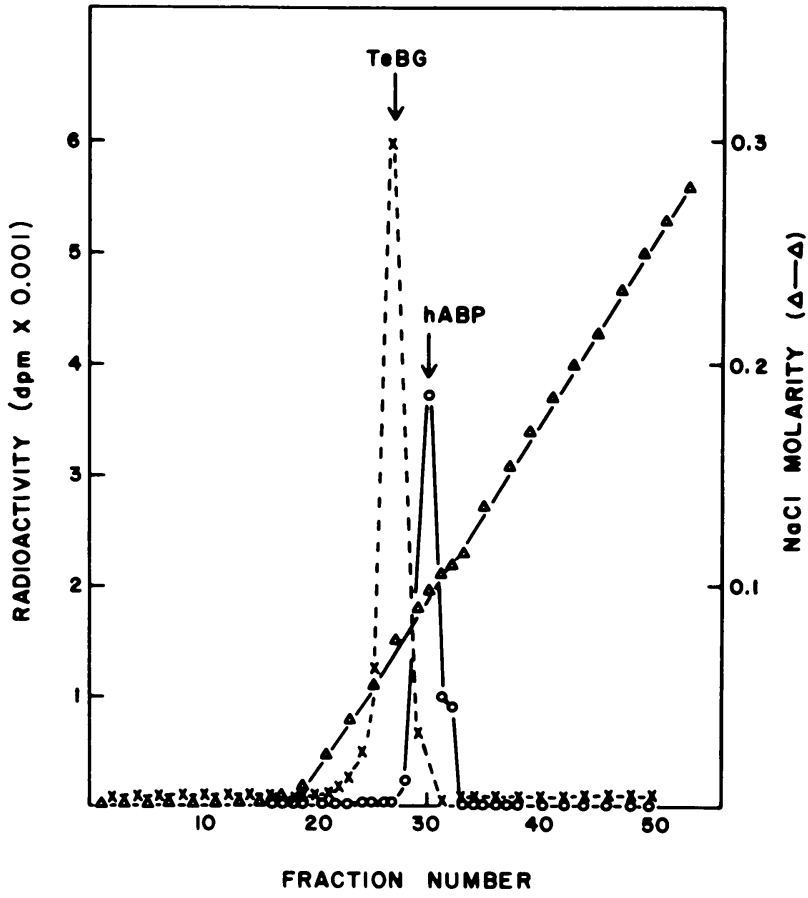

Figure 3 DEAE-cellulose chromatography of hABP and TeBG. hABP and TeBG ( $5 \mathrm{mg}$ of each protein) were dialyzed for $24 \mathrm{~h}$ at $4^{\circ} \mathrm{C}$ against $10 \mathrm{mM}$ Tris-Cl buffer ( $\mathrm{pH} 7.4$ ) containing $1 \%$ glycerol. The proteins were then applied to a column $(1 \times 10 \mathrm{~cm})$ of DEAE-cellulose equilibrated with the above buffer. The column was then eluted with $20 \mathrm{ml}$ of the equilibrating buffer, and a gradient elution was carried out with a total of $100 \mathrm{ml}$ of equilibrating buffer containing $\mathrm{NaCl}$ over a concentration range of $0.01-0.3 \mathrm{M}$. An aliquot ( $1 \mathrm{ml}$ ) of each fraction was assayed for binding activity as described under Fig. 1. Profiles represent the specific binding for hABP and TeBG. The molarity of $\mathrm{NaCl}$ was determined by conductivity on a Beckman model MG conductivity meter.

mobility of hABP after neuraminidase treatment was reduced from $R_{f} 0.37$ to 0.20 . Neuraminidase treatment reduced the mobility of TeBG from $R_{f} 0.34$ to 0.23 .

Additional stability studies of $h A B P$. Besides the above-described physicochemical properties of hABP, hABP has the following properties which are similar to rat $\mathrm{ABP}$. The binding activity of hABP was not changed by the addition of $1 \mathrm{mM}$ PCMPS or charcoal absorption overnight. After similar treatment with protease digestion, the binding activity of hABP was completely destroyed.

\section{DISCUSSION}

In attempting to demonstrate the presence of an androgen binding protein in human testicular cytosol, it was first necessary to minimize the presence of extracellular components either from the plasma or inter- 


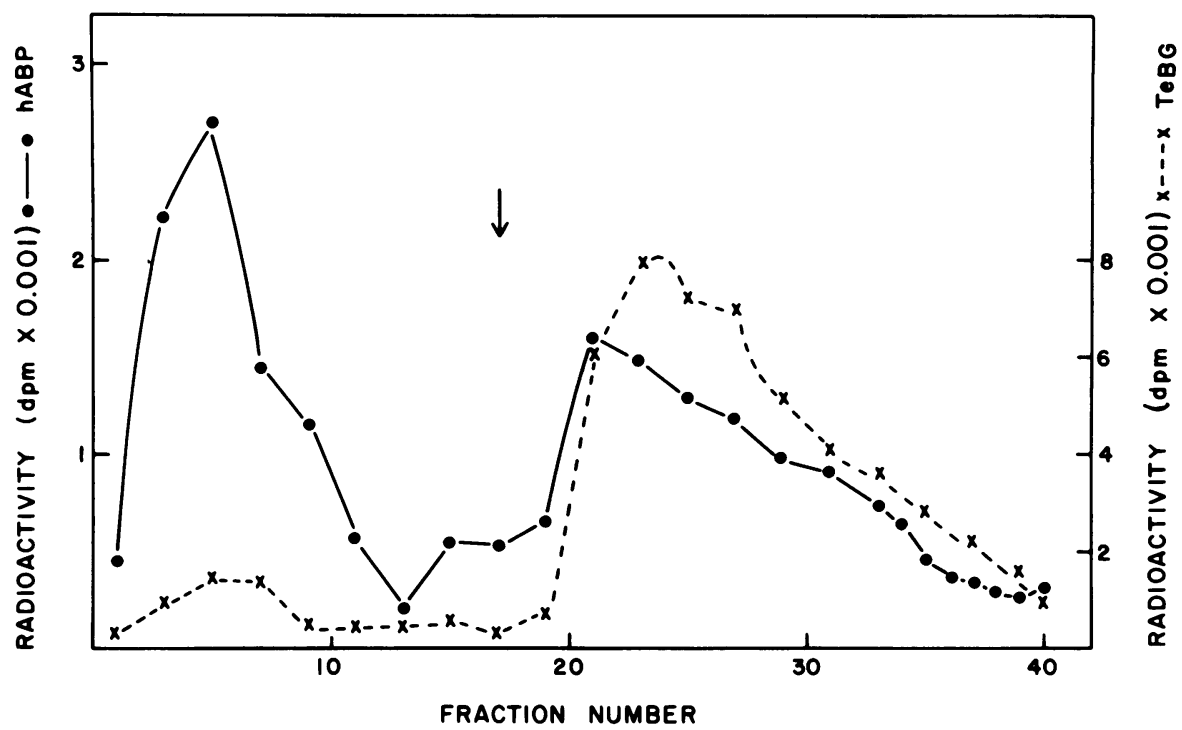

Figure 4 Concanavalin A Sepharose affinity chromatography of hABP and TeBG. hABP $(-1)$ and $\mathrm{TeBG}(\times---\times)(5 \mathrm{mg}$ of protein each) were chromatographed on columns $(1 \times 5 \mathrm{~cm})$ of concanavalin A Sepharose, which were eluted with $18 \mathrm{ml}$ of an eluting buffer (50 mM Tris-Cl, $0.5 \mathrm{M}$ sodium chloride, $\mathrm{pH} 7.4$ ) and then were eluted by an additional $25 \mathrm{ml}$ of eluting buffer containing $10 \%$ (wt/vol) $\alpha$-methylglucoside (arrow). Fractions of $1 \mathrm{ml}$ were collected, and an aliquot $(800 \mu \mathrm{l})$ from each fraction was assayed for binding activity as described under Fig. 1. The profiles represent specific binding.

stitial fluid in the preparation and subsequent analysis of the cytosol. This became particularly important in view of the presence of an androgen binding protein, TeBG, circulating in the plasma. Accord- ingly, the preparation of human testicular cytosol used in the present studies took place after a presoaking and gentle centrifugation procedure. This effectively removed more than $90 \%$ of the albumin which other-

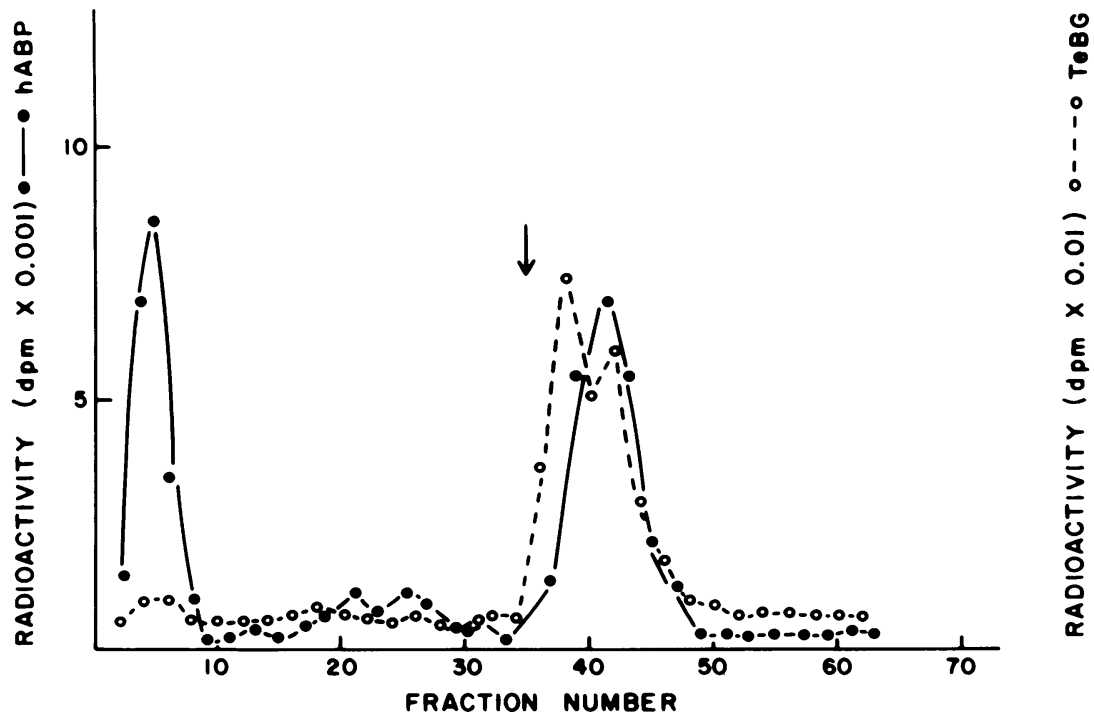

FIGURE 5 Ricin Sepharose affinity chromatography of hABP and TeBG. hABP $(-<-\bigcirc)$ and TeBG $\left(O_{--1}\right)$ ( $10 \mathrm{mg}$ of protein each) were chromatographed on columns $(1 \times 5 \mathrm{~cm})$ of ricin Sepharose. The columns were eluted with $30 \mathrm{ml}$ of eluting buffer $(0.1 \mathrm{M}$ sodium phosphate, $0.15 \mathrm{M}$ sodium chloride, $\mathrm{pH} 7.4$ ), and then were eluted by an additional $30 \mathrm{ml}$ of eluting buffer containing $0.2 \mathrm{M}$ D-galactose (arrow). Fractions of $1 \mathrm{ml}$ were collected, and an aliquot $(800 \mu \mathrm{l})$ from each fraction was assayed for binding activity as described under Fig. 1. The profiles represent specific binding. 
wise could be found in routine preparations of human testicular cytosol from intact tissue. Others have used albumin as a marker for contamination (19) and this appears to be a reliable indicator of the efficiency with which plasma components are excluded from the final cytosol preparation. Although the small amounts of albumin still remaining after the presoaking and centrifugation process were later separated by ammonium sulfate precipitation, it is recognized that this step in itself would not serve to separate TeBG from testicular cytosol binding protein. However, in view of the known ratio of albumin to $\mathrm{TeBG}$, the large proportion of albumin removed by the presoaking process would appear a reasonable indicator of the concurrent removal of most, if not all, of the TeBG that might be present. Although some loss of the testicular androgen binding protein might also take place during this process, the characteristics of the androgen binding protein would not be altered.

In preliminary studies it was found that storage of testicular tissue before preparation resulted in an increase of nonspecific binding and the appearance of multiple peaks on electrophoresis. With preparation of cytosol from testis tissue promptly after operation, nonspecific binding remained at a minimum and homogeneous results were observed on PAGE.

After the above presoaking treatment, a definite androgen binding protein, hABP, was demonstrated in the reconstituted testicular cytosol. This material had characteristics similar to that of other androgenbinding proteins such as rat ABP. The hABP binds rapidly to $\left[{ }^{3} \mathrm{H}\right] \mathrm{DHT}$ and remains stable for at least $24 \mathrm{~h}$ at $0^{\circ} \mathrm{C}$. The binding is proportional to the amount of ligand present and is linear up to $1.5 \mathrm{pmol}$ of $\left[{ }^{3} \mathrm{H}\right] \mathrm{DHT}$. The dissociation constant of $\mathrm{hABP}$ is very similar to that obtained with rat ABP as reported by Ritzen et al. (14). The $4.6 \mathrm{~S}$ sedimentation rate of $\left[{ }^{3} \mathrm{H}\right] \mathrm{hABP}-\mathrm{DHT}$ complex is similar to that of rat ABP but differs from the intracellular receptor found in target tissues $(7,8)$. Other characteristics of the hABP such as EinsteinStokes radius, calculated molecular weight, reversibility of binding, charcoal absorption, reaction to protease and PCMPS treatment are also similar to the characteristics of rat ABP as reported by Hansson, Ritzen, and other laboratories $(1-6,14)$. There are some differences from rat $\mathrm{ABP}$ in that hABP is sensitive to heating at $50^{\circ} \mathrm{C}$ for $30 \mathrm{~min}$ whereas rat $\mathrm{ABP}$ is very stable on heating at $50^{\circ} \mathrm{C}$ for $30 \mathrm{~min}$. The half-life of DHT-hABP complex is $100-120 \mathrm{~min}$ at $0^{\circ} \mathrm{C}$, considerably longer than the rat ABP-DHT complex which has a half-life of 3-6 min. On the basis of these physicochemical characteristics, hABP appears to be similar to rat $\mathrm{ABP}$ but distinctly different from intracellular receptor protein as characterized in target organ tissue.

Under our experimental conditions no intracellular androgen receptors were found in our human testis preparation. This may be due to the absence of a significant amount of biologically active receptors at the ages of the patients studied or may be because of the long half-life or slow dissociation of endogenous steroids from the receptor.

Because of the similarity previously reported between rat ABP and human TeBG (9), extensive studies comparing the physicochemical characteristics of hABP and TeBG were carried out. The molecular weights as determined were not significantly different and there was similarity in heat labilty of the two compounds. Small differences in ionic properties between hABP and TeBG were suggested on PAGE when, at different concentrations of gel, slightly different mobilities were obtained for the two materials. The relative binding affinity for various steroids was the same. The $\mathrm{pH}$ sensitivity curves for hABP and TeBG were different, with a sharp $\mathrm{pH}$ curve for hABP and a bell-shaped curve with a greater stability of binding for TeBG.

The dissociation constant for hABP $(7.8 \mathrm{nM})$ is higher than that for TeBG $(0.66 \mathrm{nM})$. The half-life of dissociation at $0^{\circ} \mathrm{C}$ was $100-120 \mathrm{~min}$ for hABP and $67-70 \mathrm{~min}$ for TeBG. It should be noted that in initial studies, before removal of plasma contaminants, a fast association binding protein with a half-life of $20-30 \mathrm{~min}$ was observed in testicular cytosol. This was identified subsequently as a human albumin contaminant which was not present with the technique used for the present studies.

Further differences in hABP and TeBG emerge when one studies the charge properties which can be demonstrated by ion-exchange chromatography. hABP binding to DEAE cellulose demonstrates a slightly more negative charge than TeBG. In other studies not presented here, isoelectric focusing of hABP yielded major peaks at $\mathrm{pH} 4.92,3.89$, and 3.25 whereas TeBG focused major peaks at $\mathrm{pH} 5.64$, 5.05 , and 4.90 on a pH gradient of 4-6. Again, these results support the contention that hABP is more acidic than TeBG.

The plant lectin affinity chromatography served to provide evidence of the glycoprotein nature of hABP as well as further indicating differences between it and TeBG. The mannose, glucose, or galactose content or configuration appears to be different. Finally, the presence of sialic acid residue of hABP is suggested by the neuraminidase treatment studies. The changes in mobility of hABP and TeBG after neuraminidase treatment could not be extrapolated quantitatively to differences in sialic acid content. It is possible that hABP has a greater sialic acid content and this would provide an explanation for the more acidic properties of hABP on ionic exchange chromatography, PAGE, and isoelectric focusing. 
It has been suggested that the presence of $\mathrm{ABP}$ in human testicular cytosol most likely derives from blood contamination (20). Albumin was uniformly present in their cytosol preparations. However, pretreatment as described in our study appeared to minimize plasma contamination as indicated by albumin as a marker.

Our results indicate many physical similarities between hABP and TeBG as noted by Vigersky et al. (20). However, a series of differences between hABP and TeBG also emerges, e.g., $\mathrm{pH}$ sensitivity, half-life of dissociation, and dissociation constant. Further, ion exchange chromatography indicates different charge characteristics of hABP and TeBG. The presence of charge isomers of $\mathrm{ABP}$ from human testis cytosol distinguishable from TeBG was also reported by Vigersky et al. (20). The presence of these differences plus the reduction of plasma contamination as marked by albumin suggest to us that the human mature testis contains an androgen binding protein separate from that which circulates in plasma. The marked similarity between TeBG and hABP may result from their having the same protein backbone, and the differences elicited may be the result of different carbohydrate content of the oligosaccharide side chain of the glycoprotein.

The presence of a "family" of similar androgen binding proteins may be considered analogous to the presence of isozymes in different tissues. Several different mechanisms have been postulated to explain the varied nature of isozymes (21). Similar mechanisms may be operative for androgen binding proteins.

Although there has been a negative study concerning the presence of $\mathrm{ABP}$ in rete testis fluid of monkeys (20), a preliminary report by others indicates the demonstration of $\mathrm{ABP}$ in rete testis fluid of monkeys and man (22).

The specific function of hABP in humans has not yet been studied. Our initial studies indicate a decreasing number of binding sites of hABP in the aging testis (23). This would be in keeping with a regulatory role of hABP in the transport and availability of androgens in various aspects of testicular function.

\section{ACKNOWLEDGMENT}

The expert technical assistance of Mrs. Deborah Stratico and Mrs. Virginia Sunday is gratefully acknowledged.

\section{REFERENCES}

1. French, F. S., and E. M. Ritzen. 1973. A high-affinity androgen-binding protein (ABP) in rat testis: Evidence for secretion into efferent duct fluid and absorption by epididymis. Endocrinology. 93: 88-95.
2. Hansson V. 1972. Further characterization of the $5 \alpha$ dihydrotestosterone binding protein in the epididymal cytosol fraction, in vitro studies. Steroids. 20(5): 575596.

3. Hansson, V., (. Djoseland, E. Reusch, A. Attramadal, and (). Torgersen. 1973. An androgen binding protein in the testis cytosol fraction of adult rats, comparison with the androgen binding protein in the epididymis. Steroids. 21(3): 457-474.

4. Hansson, V., E. M. Ritzen, F. S. French, and S. N. Nayfeh. 1975. Androgen transport and receptor mechanism in testis and epididymis. Handb. Physiol. 5(Sect. 7. Endo(rinology.): 173-201.

5. Hansson, V., O. Trygstad, F. S. French, W. S. McLean, A. A. Smith, D. J. Tindall, S. C. Weddington, P. Petrusz, S. N. Nayfeh, and E. M. Ritzen. 1974. Androgen transport and receptor mechanisms in testis and epididymis. Nature (Lond.). 250: 387-391.

6. Ritzen, E. M., and F. S. French. 1974. Demonstration of an androgen binding protein (ABP) in rabbit testis: Secretion in efferent duct fluid and passage into epididymis. J. Steroid Biochem. 5: 151-154.

7. Hansson, V., W. S. McLean, A. A. Smith, D. J. Tindall, S. C. Weddington, S. N. Nayfeh, F. S. French, and E. M. Ritzen. 1974. Androgen receptor in rat testis. Steroids. 23: $823-832$.

8. Hansson, V., O. Djoseland, E. Reusch, A. Attramadal, and O. Torgersen. 1973. Intracellular receptors for $5 \alpha$ dihydrotestosterone in the epididymis of adult rats. Comparison with the androgenic receptors in the ventral prostate and the androgen binding protein (ABP) in the testicular and epididymal fluid. Steroids. 22(1): 19-33.

9. Weddington, S. C., W. S. McLean, S. N. Nayfeh, and F. S. French. 1974. Androgen binding protein (ABP) in rabbit testis and epididymis. Steroids. 24(1): 123-134.

10. Weddington, S. C., V. Hansson, E. M. Ritzen, L. Hagenas, F. S. French, and S. N. Nayfeh. 1975. Sertoli cell secretory function after hypophysectomy. Nature. (Lond.). 254: $145-146$.

11. Tindall, D. J., and A. R. Means. 1976. Concerning the hormonal regulation of androgen binding protein in rat testis. Endocrinology. 99: 809-818.

12. Murphy, B. E. P. 1967. Some studies of the proteinbinding of steroids and their application to the routine micro and ultramicro measurement of various steroids in body fluids by competitive protein-binding radioassay. J. Clin. Endocrinol. Metab. 27: 973-990.

13. Pearlman, W. H., and O. Crepy. 1967. Steroid-protein interaction with particular reference to testosterone binding by human serum. J. Biol. Chem. 212: 182-189.

14. Ritzen, E. M., M. C. Dobbins, D. J. Tindall, F. S. French, and S. N. Nayfeh. 1973. Characterization of an androgenbinding protein (ABP) in rat testis and epididymis. Steroids. 21(4): 593-607.

15. Martin, R. C., and B. N. Ames. 1961. A method for determining the sedimentation behavior of enzymes: application to protein mixtures. J. Biol. Chem. 236: $1372-1379$.

16. Ritzen, E. M., F. S. French, S. C. Weddington, S. N. Nayfeh, and V. Hansson. 1974. Steroid binding in polyacrylamide gel. J. Biol. Chem. 249: 6597-6604.

17. Lowry, O. H., N. J. Rosebrough, A. L. Farr, and R. J. Randall. 1951. Protein measurement with the Folin phenol reagent. J. Biol. Chem. 193: 265-275.

18. Laurent, T. C., and J. Killander. 1964. A theory of gel filtration and its experimental verification. J. Chromatogr. 14: $317-330$. 
19. Wagner, R. K., and P. W. Jungblut. 1976. Differentiation between steroid hormone receptors CBG and SHBG in human target organ extracts by a single assay. Mol. Cell. Endocr. 4: 13-24.

20. Vigersky, R. A., D. L. Loriaux, S. S. Howard, G. B. Hodgen, M. B. Lipsett, and A. Chrambach. 1976. Androgen binding proteins of testis, epididymis, and plasma in man and monkey. J. Clin. Invest. 58: 1061-1068.
21. Hopkinson, D. A. 1974. Isozymes. J. Clin. Pathol.(Lond.). 8(Suppl. 27) (R. Coll. Pathol.): 122-127.

22. Hansson, V. 1977. In The Testis in Normal and Infertile Men. P. Troen and H. R. Nankin, editors. Raven Press, New York. 433.

23. Hsu, A. F., H. R. Nankin, and P. Troen. 1977. Androgenbinding protein in human testis: Effect of age. In The Testis in Normal and Infertile Men. P. Troen and H. R. Nankin, editors. Raven Press, New York. 421-427. 